\title{
Prevalence of Scabies in the Covid-19 Pandemic Period and Determination of Risk Factors for Scabies: a Hospital-Based Cross-Sectional Study in Northeast Turkey
}

\author{
Z. Karaca Ural ${ }^{1}$ D . B. Çatak ${ }^{2}$ E. Ağaoğlu ${ }^{1}$
}

Received: 6 September 2021 / Accepted: 18 January 2022 / Published online: 2 February 2022

(c) The Author(s) under exclusive licence to Witold Stefański Institute of Parasitology, Polish Academy of Sciences 2022

\begin{abstract}
Background There is an increase in the incidence of scabies in Turkey, which started before the Covid-19 pandemic, and this situation is considered as an epidemic. With this study, we aimed to reveal the prevalence of scabies during the pandemic period and the risk factors that are effective in the transmission of scabies.

Methods Our study was performed as a cross-sectional study in 376 patients who applied to our dermatology outpatient clinic between 1st and 30th April 2021. Sociodemographic and socioeconomic characteristics, living space, health behavior, and health care utilization of the patients were questioned.

Results The prevalence of scabies was determined as $10.9 \%$. Features such as sex, area of residence, age, formal education status, employment status, total income, number of shower, number of people per room, water source, and heating method, which were found to be significant as a result of the double test, were included in the logistic regression analysis. Scabies was found 2.728 times (CI 1.325-5.557) more in those who live in rural areas than those who live in urban areas, 2.714 times (CI 1.365-5.451) more in men than women, 2.707 times (CI 1.256-5.833) more in nonworking than working, 2.354 times (CI 1.057-5.243) more in those with less than 9 showers per month than those with 9 or more showers per month. Conclusion During the Covid-19 pandemic period, the prevalence of scabies in Turkey is increasing and it is becoming a serious health problem. Our study emphasizes this increase and determines the risk factors for transmission.
\end{abstract}

Keywords Covid-19 $\cdot$ Outbreak $\cdot$ Scabies $\cdot$ Pandemic $\cdot$ Prevalence

\section{Introduction}

Human scabies is a parasitic disease caused by Sarcoptes scabiei var. hominis. It can cause various problems in different organs and tissues [1-4] and at the mental and social level in sick people. In other words, the complications and secondary effects of scabies cause a huge public health burden $[5,6]$.

Scabies is one of the most common dermatological conditions in developing countries. Globally, it is estimated to affect more than 200 million people at any time. According

Z. Karaca Ural

zeynepkaraca.zk90@gmail.com

1 Department of Dermatology, Kars Harakani State Hospital, Kars, Turkey

2 Department of Public Health, School of Medicine, Kafkas University, Kars, Turkey to the current literature, its incidence in the world varies between 0.20 and $71.0 \%$ [1]. In Turkey, it is emphasized that there is an increase in cases of scabies both before and during the Covid-19 pandemic, and this situation is considered as an epidemic of scabies [7-9].

Scabies, which is included in the group of neglected tropical diseases by WHO (World Health Organization), is mainly transmitted through direct contact or fomites. Sociodemographic, socioeconomic, biodemographic, and environmental factors are effective in the transmission of the parasite $[1,2,10,11]$.

In the study, it was aimed to determine the prevalence of scabies and the factors affecting the scabies disease among patients who applied to the dermatology outpatient clinic of a secondary hospital for any reason during the Covid-19 period. 


\section{Materials and Methods}

\section{Identification of the Study Area}

The region where the study was conducted is bordered by Iran, Georgia, Azerbaijan, and Armenia. The main livelihood of the region is agriculture and animal husbandry. It is below the Turkey average in terms of socioeconomic development. Illiterate people constitute $11.7 \%$ of the total population of the region, and those who have not completed any school constitute $13.5 \%$ [12]. It is below the Turkey average in terms of health personnel per thousand people. Respectively, the infant mortality rate is 11.2 per thousand, and the maternal mortality rate is 24.5 per hundred thousand, which are above the Turkey average (Turkey averages, respectively, the infant mortality rate is 6.8 per thousand, and the maternal mortality rate is 14.6 per hundred thousand) [13].

\section{Type of the Study}

This is a hospital-based cross-sectional study.

\section{The Universe and Sample of the Study}

The data of the year 2020 were used to determine the universe of the study. In 2020, the number of people applied to the dermatology outpatient clinic due to a disease is 20729 . After the duplicate applications were removed, the remaining 14,763 people constituted the universe of the study. It is anticipated that the same number of people will apply in 2021 , and the population of the study was determined as 14,763 people. Sample size of the study was calculated with the formula $n=N t^{2} p q / d^{2}(N-1)+t^{2} p q . N$ is the number of individuals in the universe, $n$ is the number of individuals to be sampled, $p$ is the prevalence (probability) of the event under investigation, $q$ is the prevalence of non-occurrence (probability) of the event under investigation; $t$ is the theoretical value found in the table $t$ at a given degree of freedom and the detected error margin, $d$ is the desired \pm deviation according to the prevalence of the event. Accordingly, when $p=0.50, q=0.50, t=1.96$, and $d=0.05$, the sample size was determined as 374 people.

\section{Verbal/Written Consent and Ethics Committee Approval}

The data of the study were collected after the approval of the local ethics committee (dated 31.03.2021 and numbered 80576354-050-991/38) and written consent from the hospital administration and verbal consent from the patients.

\section{Configuring the Data Collection Form}

The data collection form of the study was prepared by the researchers by scanning the literature.

\section{The Dependent Variable of the Study}

Presence of scabies in people applying to dermatology outpatient clinic. According to the 2020 International Alliance for the Control of Scabies (IACS) consensus criteria for the diagnosis of scabies, all patients who were considered to have confirmed scabies, clinical scabies or suspected scabies were diagnosed with scabies by 2 independent dermatologists [14].

\section{The Independent Variable of the Study}

Sociodemographic, environmental, socioeconomic, and health-related characteristics formed the independent variables of the study.

\section{Preliminary Testing of the Study}

It was conducted with five patients who applied to the outpatient clinic and were not included in the study. After the preliminary testing, the necessary corrections were made to the data collection form.

\section{Selection of Participants for the Study and Data Collection}

Data were collected between 1st and 30th April 2021 using face-to-face interview technique. The data were collected by two dermatologists who conducted the study.

\section{Statistical Analysis}

The Chi-square test was used in binary analysis. The variables that were statistically significant $(p<0.05)$ in the Chisquare test were taken into Backward LR logistic regression analysis.

\section{Results}

Three hundred and seventy-six people participated in this cross-sectional study and the prevalence of scabies was determined as $10.9 \% .4 .9 \%$ (2 patients) of 41 scabies cases had a previous history of scabies. $19.5 \%$ of the cases $(8$ 
patients) received antiparasitic treatment in a primary care center for their present complaints before consulting a dermatologist but did not benefit. Secondary infection was present in $9.8 \%$ of cases ( 4 cases). Considering the location of the lesions, there was generalized localization in $48.8 \%$ (20 cases) of the cases.

Table 1 shows the effects of sociodemographic and socioeconomic characteristics on scabies. Accordingly, there was a statistically significant difference between the presence of scabies and some sociodemographic characteristics of the patient which are sex, area of residence, and age (respectively, $p=0.015, p=0.001$, and $p=0.020$ ). There was no statistically significant difference between scabies and the patient's marital status, family type, and the number of households ( $p=0.523, p=0.541, p=0.779$, respectively).

When evaluated in terms of socioeconomic characteristics, there was a statistically significant difference between the presence of scabies and formal education status, employment status, and family income (respectively, $p=0.004$, $p=0.005, p=0.029)$. There was no statistically significant difference between health insurance and the presence of scabies $(p=0.914)$ (Table 1$)$.

Table 2 shows the effects of health behavior and environmental factors on scabies. When the table was followed, while there was a statistically significant difference between bathing status, which is one of the health behaviors, and scabies $(p=0.001)$, there was no statistically significant difference between scabies and sharing a bed with any person in the house, wearing a common dress, having an active sexual life, sharing the same bed with one's spouse, duration of staying at home during the Covid-19 pandemic, having a chronic disease and being hospitalized during the Covid19 period (respectively, $p=0.119, p=0.274, p=0.544$, $p=0.260, p=0.471, p=0.541, p=0.672$ ).

While a statistically significant difference was found between scabies and some of the environmental factors, which are numbers of people per room, water source, and heating method (respectively, $p=0.020, p=0.032$, $p=0.001)$, there was no statistically significant difference between where the toilet is located and scabies $(p=0.114)$.

Table 1 Distribution of sociodemographic and socioeconomic characteristics over scabies

\begin{tabular}{|c|c|c|c|c|c|c|}
\hline \multirow[t]{3}{*}{ Independent variables } & & \multicolumn{2}{|c|}{ Dependent variable } & \multirow{3}{*}{$\begin{array}{l}\text { Total } \\
\text { Number }(\%)^{\ddagger}\end{array}$} & \multirow[t]{3}{*}{$X^{2}$} & \multirow[t]{3}{*}{$p$} \\
\hline & & \multirow{2}{*}{$\begin{array}{l}\text { Have scabies } \\
\text { Number }(\%)^{\dagger}\end{array}$} & \multirow{2}{*}{$\begin{array}{l}\text { Have no scabies } \\
\text { Number }(\%)^{\dagger}\end{array}$} & & & \\
\hline & & & & & & \\
\hline \multicolumn{7}{|c|}{ Sociodemographic characteristics } \\
\hline \multirow[t]{2}{*}{ Sex } & Male & $24(15.6)$ & $130(84.4)$ & $154(41.0)$ & 5.881 & 0.015 \\
\hline & Female & $17(7.7)$ & $205(92.3)$ & $222(59.0)$ & & \\
\hline \multirow[t]{2}{*}{ Area of residence } & Town/village & $21(21.6)$ & $76(78.4)$ & $97(25.8)$ & 15.536 & 0.001 \\
\hline & City/County & $20(7.2)$ & $259(92.8)$ & $279(74.2)$ & & \\
\hline \multirow[t]{2}{*}{ Age } & $\leq 19$ & $17(17.2)$ & $82(82.8)$ & $99(26.3)$ & 5.433 & 0.020 \\
\hline & $\geq 20$ & $24(8.7)$ & $253(91.3)$ & $277(73.7)$ & & \\
\hline \multirow[t]{2}{*}{ Marital status } & Still married & $15(9.7)$ & $140(90.3)$ & $155(41.2)$ & 0.409 & 0.523 \\
\hline & Not married & $26(11.8)$ & $195(88.2)$ & $221(58.8)$ & & \\
\hline \multirow[t]{2}{*}{ Family type } & Extended family & $10(9.3)$ & $97(90.7)$ & $107(28.5)$ & 0.374 & 0.541 \\
\hline & Nuclear family & $31(11.5)$ & $238(88.5)$ & $269(71.5)$ & & \\
\hline \multirow[t]{2}{*}{ Number of households } & $\leq 4$ & $22(11.3)$ & $172(88.7)$ & $194(51.6)$ & 0.078 & 0.779 \\
\hline & $\geq 5$ & $19(10.4)$ & $163(89.6)$ & $183(48.4)$ & & \\
\hline \multicolumn{7}{|c|}{ Socioeconomic characteristics } \\
\hline \multirow[t]{2}{*}{ Formal education } & Never had & $9(25.0)$ & $27(75.0)$ & $36(9.6)$ & 8.142 & 0.004 \\
\hline & $\mathrm{Had}$ & $32(9.4)$ & $308(90.6)$ & $340(90.4)$ & & \\
\hline \multirow[t]{2}{*}{ Employment status } & Nonworking & $29(15.3)$ & $160(84.7)$ & $189(50.3)$ & 7.710 & 0.005 \\
\hline & Working & $12(6.4)$ & $175(93.6)$ & $187(49.7)$ & & \\
\hline \multirow[t]{2}{*}{ Health insurance } & No & $3(11.5)$ & $23(88.5)$ & $26(6.9)$ & 0.012 & 0.914 \\
\hline & Yes & $38(10.9)$ & $312(89.1)$ & $350(93.1)$ & & \\
\hline \multirow[t]{2}{*}{ Total income } & Unsatisfying & $35(13.2)$ & $213(86.8)$ & $266(70.7)$ & 4.753 & 0.029 \\
\hline & Satisfying & $6(5.5)$ & $104(94.5)$ & $110(29.3)$ & & \\
\hline Total & & $41(10.9)$ & $335(89.1)$ & $376(100.0)$ & & \\
\hline
\end{tabular}

${ }^{\dagger}$ Percentage of lines

${ }^{\ddagger}$ Percentage of columns 
Table 2 Effects of health behaviors and environmental factors on scabies

\begin{tabular}{|c|c|c|c|c|c|c|}
\hline \multirow[t]{3}{*}{ Independent variables } & & \multicolumn{2}{|c|}{ Dependent variable } & \multirow[t]{2}{*}{ Total } & & \multirow[t]{3}{*}{$p$} \\
\hline & & \multirow{2}{*}{$\begin{array}{l}\text { Have scabies } \\
\text { Number }(\%)^{\dagger}\end{array}$} & \multirow{2}{*}{$\begin{array}{l}\text { Have no scabies } \\
\text { Number }(\%)^{\dagger}\end{array}$} & & & \\
\hline & & & & Number $(\%)^{\frac{\hbar}{4}}$ & & \\
\hline \multicolumn{7}{|l|}{ Health behaviors } \\
\hline \multirow[t]{2}{*}{ Shared bed (with anyone) } & Yes & $10(7.5)$ & $123(92.5)$ & $133(35.4)$ & 2.478 & 0.119 \\
\hline & No & $31(12.8)$ & $212(87.2)$ & $243(64.6)$ & & \\
\hline \multirow[t]{2}{*}{ Shared bed (with one's spouse) } & Yes & $10(8.3)$ & $110(91.7)$ & $120(31.9)$ & 1.199 & 0.274 \\
\hline & No & $31(12.1)$ & $225(87.9)$ & $256(68.1)$ & & \\
\hline \multirow[t]{2}{*}{ Common dress } & Yes & $5(8.6)$ & $53(91.4)$ & $58(15.4)$ & 0.368 & 0.544 \\
\hline & No & $36(11.3)$ & $282(88.7)$ & $318(84.6)$ & & \\
\hline \multirow[t]{2}{*}{ Active sexual life } & Yes & $9(8.1)$ & $102(91.9)$ & $111(29.5)$ & 1.267 & 0.260 \\
\hline & No & $32(12.1)$ & $233(87.9)$ & $265(70.5)$ & & \\
\hline \multirow[t]{2}{*}{ Duration of staying at home } & Increased & $29(11.7)$ & $218(88.3)$ & $247(65.7)$ & 0.519 & 0.471 \\
\hline & Unchanged & $12(9.3)$ & $117(90.7)$ & $129(34.3)$ & & \\
\hline \multirow[t]{2}{*}{ Additional disease } & Yes & $4(8.3)$ & $44(91.7)$ & $48(12.8)$ & 0.374 & 0.541 \\
\hline & No & $37(11.3)$ & $291(88.7)$ & $328(87.2)$ & & \\
\hline \multirow[t]{2}{*}{ Hospitalized } & Yes & $3(13.6)$ & $19(86.4)$ & $22(5.9)$ & 0.180 & 0.672 \\
\hline & No & $38(10.7)$ & $316(89.3)$ & $354(94.1)$ & & \\
\hline \multirow[t]{2}{*}{ Bathing (month) } & Below the median $(9<)$ & $32(15.0)$ & $181(85.0)$ & $213(56.6)$ & 8.581 & 0.003 \\
\hline & Above the median $(9 \geq)$ & $9(5.5)$ & $154(94.5)$ & $163(43.4)$ & & \\
\hline \multicolumn{7}{|l|}{ Environmental factors } \\
\hline \multirow[t]{2}{*}{ Number of people per room } & $<3$ & $21(16.0)$ & $110(84.0)$ & $131(34.8)$ & 5.438 & 0.020 \\
\hline & $3 \geq$ & $20(8.2)$ & $225(91.8)$ & $245(65.2)$ & & \\
\hline \multirow[t]{2}{*}{ Water source } & City & $29(9.3)$ & $282(90.7)$ & $311(82.7)$ & 4.620 & 0.032 \\
\hline & Spring & $12(18.5)$ & $53(81.5)$ & $65(17.3)$ & & \\
\hline \multirow[t]{2}{*}{ Place of the toilet } & Inside home & $32(9.9)$ & $291(90.1)$ & $323(85.9)$ & 2.504 & 0.114 \\
\hline & Outside home & $9(17.0)$ & $44(83.0)$ & $53(14.1)$ & & \\
\hline \multirow[t]{2}{*}{ Heating method } & Stove & $22(19.0)$ & $94(81.0)$ & $116(30.9)$ & 11.221 & 0.001 \\
\hline & Calorifire & $19(7.3)$ & $241(92.7)$ & $260(69.1)$ & & \\
\hline Total & & $41(10.9)$ & $335(89.1)$ & $376(100.0)$ & & \\
\hline
\end{tabular}

$\dagger$ Percentage of lines

¥Percentage of columns

Variables that were statistically significant in binary comparisons in Tables 1 and 2 were included in the logistic regression analysis.

Table 3 shows the results of logistic regression (backward: LR) analysis. Scabies was found 2.728 times (CI 1.325-5.557) more in those who live in rural areas than those who live in urban areas, 2.714 times (CI 1.365-5.451) more in men than women, 2.707 times (CI 1.256-5.833) more in nonworking than working, 2.354 times (CI 1.057-5.243) more in those with less than 9 showers per month than those with 9 or more showers per month.

\section{Discussion}

Scabies can occur worldwide and in people of all classes. However, while cases are seen sporadically in developed countries, it progresses as epidemics in poor countries (especially in countries where overcrowding and poverty coexist, and access to treatment is limited) [1]. In this study, it was aimed to determine the prevalence of scabies and the risk factors for scabies among patients who applied to the dermatology outpatient clinic of a public secondary hospital. 
Table 3 Results of logistic regression analysis

\begin{tabular}{|c|c|c|c|c|c|c|}
\hline Independent variables & & B & SE & Wald & Odds ratio & $\begin{array}{l}95 \% \mathrm{CI} \\
(\min -\max \\
\text { values })^{\dagger}\end{array}$ \\
\hline Area of residence & $\begin{array}{l}\text { Rural } \\
\text { Urban }\end{array}$ & 1.004 & 0.353 & 8.073 & $\begin{array}{l}2.728 \\
1 \text { (reference) }\end{array}$ & $1.325-5.557$ \\
\hline Sex & $\begin{array}{l}\text { Male } \\
\text { Female }\end{array}$ & 0.998 & 0.366 & 7.453 & $\begin{array}{l}2.714 \\
1 \text { (reference) }\end{array}$ & $1.365-5.451$ \\
\hline Employment status & $\begin{array}{l}\text { Nonworking } \\
\text { Working }\end{array}$ & 0.996 & 0.392 & 6.462 & $\begin{array}{l}2.707 \\
1 \text { (reference) }\end{array}$ & $1.256-5.833$ \\
\hline Number of baths per month & $\begin{array}{l}9< \\
9 \geq\end{array}$ & 0.856 & 0.409 & 4.390 & $\begin{array}{l}2.354 \\
1 \text { (reference) }\end{array}$ & $1.057-5.243$ \\
\hline
\end{tabular}

${ }^{\dagger}$ Minimum-maximum values
The prevalence of scabies was found to be $10.9 \%$ in the study. While the prevalence of scabies was found to be $1.4 \%$ in geriatric patients who applied to the dermatology outpatient clinic of a tertiary hospital in Turkey between 2010 and 2014 [15], it was found to be $0.79 \%$ in another study involving all age groups [16]. In a study examining the data of the Ministry of Health between 2006 and 2017, the prevalence of scabies was determined as $2.8 \%$ [17]. On the other hand, in a study examining the records of 12 tertiary dermatology outpatient clinics for the years 2014-2019, it is stated that the cases increased up to 30 times after 2016 [7]. In studies conducted during the Covid-19 pandemic, it was stated that there was an increase in the prevalence of scabies $[8,9]$, and it was stated that the prevalence of scabies was $12.8 \%$ among patients who came to the secondary dermatology outpatient clinic. In a study conducted in Spain, it is stated that the prevalence of scabies increased during the pandemic period [18]. To summarize, in the light of the data in the literature, it is emphasized that there was a significant increase in scabies before the pandemic in Turkey and this situation is considered as an epidemic of scabies [7]. Again, it is stated that there is an increase in scabies cases in studies conducted during the pandemic in Turkey, and this situation is considered as a scabies epidemic by the authors [8,9]. It is emphasized that the increase in cases is the result of the "stay-at-home" policy implemented during the Covid-19 pandemic period. The authors explain the effects of the stay-at-home policy as follows. As a result of the stay-at-home policy, the duration of time spent at home has increased. Accordingly, contact between individuals has increased. As a result of increased contact, the risk of transmission of the parasite either through direct contact or fomites has increased $[8,9,18]$.

In the literature, no study has been found during the Covid-19 pandemic that determined risk factors for scabies transmission and had logistic regression analysis results. Therefore, the discussion will be conducted mostly with prepandemic studies, which creates a limitation in comparing risk factors. Another important point is that the compared studies are mainly field studies on students and their national income is below Turkey's.

Scabies was found 2.728 times (CI 1.325-5.557) more in those who live in rural areas than those who live in urban areas. In a cross-sectional study conducted in Ethiopia, it was reported that scabies is 2.03 (CI 1.07-3.86) times more common in rural residents than in urban residents [19]. Due to the inadequacies in both environmental and economic conditions, it is expected that scabies is more common in rural areas.

In the study, scabies is 2.714 (CI 1.365-5.451) times more common in men than in women. In support of our study, scabies was detected 2.69 (CI 1.82-3.96) times more frequently in men than in women in Ethiopia. [20]. Similarly, in a study conducted in Liberia, it was found to be lower in women (OR 0.50; CI 0.29-0.73) [21]. In a study conducted in the Solomon Islands, scabies was found to be 1.2 (CI 1.1-1.4) times more common in men than in women [22]. In Turkey, men are more active than women in working life and they spend more time outside the home. However, as a result of the stay-at-home policy, the duration of staying at home for men has increased during the pandemic period. This may play a role in the transmission of scabies.

Scabies is 2.707 (CI 1.256-5.833) times more common in nonworking than in working. It is 2.2 (CI 1.2-2.6) times higher in unemployed than employed [23]. In a study conducted in Poland, it was emphasized that unemployment is effective on scabies [24]. In a study conducted with primary school children in Turkey, it was determined that scabies was more common in children of families in which the father is unemployed [25]. Unemployment is a situation that is expected to affect the socioeconomic status of the family, and therefore, the health, nutrition, housing, etc. of the individuals in the family. Especially during the pandemic, workplaces were temporarily closed by the government. This can affect the economic status of employees of these working places. 
Scabies is 2.354 (CI 1.057-5.243) times more common in those with less than 9 showers per month than those with 9 or more showers per month It is 2.0 (CI 1.0-2.1) times more common in those who do not take bath regularly than in those who do [23]. It is 1.64 (CI 1.12-2.40) times higher in those with poor personal hygiene than in those without [20]. It is 3.95 (1.84-8.49) times more common in those who take a bath rarely than those who do not [19]. Showering and using cleaning products for personal hygiene remove immature mites from the skin, reducing the possibility of transmission of scabies infection [12]. The UK National Health Service's recommendation for keeping the body clean is daily washing of the genitals and bathing or showering at least twice a week [26].

As a result, there is an increase in the prevalence of scabies. Rural life, male sex, being unemployed, and not taking enough baths were identified as risk factors for scabies.

Acknowledgements All patients in this manuscript have given written informed consent to the publication of their case details.

Author contributions $\mathrm{KUZ}, \mathrm{CB}$, and $\mathrm{AE}$ have made substantial contributions to conception and design. KUZ and ÇB have been involved in drafting the manuscript. KUZ, ÇB, and $\mathrm{AE}$ have revised it critically for important intellectual content. KUZ, ÇB, and AE have given final approval of the version to be published. All the authors have agreed to be accountable for all aspects of the work in ensuring that questions related to the accuracy or integrity of any part of the work are appropriately investigated and resolved.

Funding None reported.

Availability of data and material The datasets generated during and/or analyzed during the current study are available from the corresponding author on reasonable request.

Code availability Not applicable.

\section{Declarations}

Conflict of interest All the authors certify that they have no affiliations with or involvement in any organization or entity with any financial interest or non-financial interest in the subject matter or materials discussed in this manuscript.

Ethics approval, consent to participate, consent for publication The data of the study were collected after the approval of the local ethics committee (dated 31.03.2021 and numbered 80576354-050-991/38) and written consent from the hospital administration and verbal consent from the patients.

\section{References}

1. https://www.who.int/news-room/fact-sheets/detail/scabies. Accessed 05 May 2021

2. Engelman D, Cantey PT, Marks M, Solomon AW, Chang AY, Chosidow O et al (2019) The public health control of scabies: priorities for research and action. Lancet 394(10192):81-92. https://doi.org/10.1016/S0140-6736(19)31136-5

3. Thornley S, Marshall R, Jarrett P, Sundborn G, Reynolds E, Schofield G (2018) Scabies is strongly associated with acute rheumatic fever in a cohort study of Auckland children. J Paediatr Child Health 54(6):625-632. https://doi.org/10.1111/jpc. 13851

4. Thean LJ, Engelman D, Kaldor J, Steer AC (2019) Scabies: new opportunities for management and population control. Pediatr Infect Dis J 38(2):211-213. https://doi.org/10.1097/INF.00000 00000002211

5. Hugdahl E (2020) Skabb-et folkehelseproblem. Tidsskrift. https:// doi.org/10.4045/tidsskr.20.0799

6. Engelman D, Kiang K, Chosidow O, McCarthy J, Fuller C, Lammie P, Steer A et al (2013) Members of the international alliance for the control of scabies. Toward the global control of human scabies: introducing the international alliance for the control of scabies. PLoS Negl Trop Dis. https://doi.org/10.1371/journal. pntd.0002167

7. Özden MG, Ertürk K, Kartal SP, Yayli S, Göktay F, Doğramacı CA et al (2020) An extraordinary outbreak of scabies in Turkey. J Eur Acad Dermatol Venereol 34(12):e818-e820. https://doi.org/ 10.1111/jdv.16699

8. Kutlu Ö, Aktaş H (2020) The explosion in scabies cases during COVID-19 pandemic. Dermatol Ther 33(5):e13662. https://doi. org/10.1111/dth.13662

9. Kutlu Ö, Güneş R, Coerdt K, Metin A, Khachemoune A (2020) The effect of the "stay-at-home" policy on requests for dermatology outpatient clinic visits after the COVID-19 outbreak. Dermatol Ther 33(4):e13581. https://doi.org/10.1111/dth.13581

10. Thomas C, Coates SJ, Engelman D, Chosidow O, Chang AY (2020) Ectoparasites: scabies. J Am Acad Dermatol 82(3):533548. https://doi.org/10.1016/j.jaad.2019.05.109

11. Debe Worku E, Asemahagn MA, Endalifer ML (2020) Determinants of scabies outbreak in Takusa district of Amhara Region. Northwest Ethiopia J Public Health Afr 11(2):1325. https://doi. org/10.4081/jphia.2020.1325

12. Toy S (2015) TRA1 Düzey 2 Bölge Planı (2014-2023); Planlama Süreci ve Kapsam1. Planlama Dergisi. https://doi.org/10.5505/ planlama.2016.18189

13. The Ministry of Health of Turkey Health Statistics Yearbook 2018. https://dosyasb.saglik.gov.tr/Eklenti/36164,siy2018en2pdf. pdf?0. Accessed 05 May 2021

14. Engelman D, Yoshizumi J, Hay R, Osti M, Micali G, Norton S et al (2020) The 2020 IACS consensus criteria for the diagnosis of scabies. Br J Dermatol. https://doi.org/10.1111/BJD.18943

15. Çölgecen E, Börekçi E, Kader Ç, Yıldırım T, Özyurt K (2015) Prevalence of skin diseases among geriatric patients in the region of Yozgat. Ankara Üniversitesi Tip Fakültesi Mecmuası 68:119-123

16. Turan Ç, Metin N, Utlu Z (2020) Epidemiological evaluation of scabies cases encountered in the last three years as a tertiary health center. Turkiye Parazitol Derg 44(2):77-82. https://doi.org/ 10.4274/tpd.galenos.2020.6796

17. Çetinkaya Ü, Sahin S, Ulutabanca RÖ (2018) The epidemiology of scabies and pediculosis in kayseri. Turkiye Parazitol Derg 42(2):134-137. https://doi.org/10.5152/tpd.2018.5602

18. Martínez-Pallás I, Aldea-Manrique B, Ramírez-Lluch M, Manuel Vinuesa-Hernando J, Ara-Martín M (2020) Scabies outbreak during home confinement due to the SARS-CoV-2 pandemic. J Eur Acad Dermatol Venereol 34(12):e781-e783. https://doi.org/10. $1111 /$ jdv. 16879

19. Dagne H, Dessie A, Destaw B, Yallew WW, Gizaw Z (2018) Prevalence and associated factors of scabies among schoolchildren in Dabat district, northwest Ethiopia, 2018. Environ Health Prev Med 24(1):67. https://doi.org/10.1186/s12199-019-0824-6 
20. Ejigu K, Haji Y, Toma A, Tadesse BT (2019) Factors associated with scabies outbreaks in primary schools in Ethiopia: a casecontrol study. Res Rep Trop Med 10:119-127. https://doi.org/10. 2147/RRTM.S214724

21. Collinson S, Timothy J, Zayzay SK, Kollie KK, Lebas E, Candy $\mathrm{N}$ et al (2020) The prevalence of scabies in Monrovia, Liberia: a population-based survey. PLoS Negl Trop Dis 14(12):e0008943. https://doi.org/10.1371/journal.pntd.0008943

22. Lake SJ, Engelman D, Sokana O, Nasi T, Boara D, Grobler AC et al (2021) Defining the need for public health control of scabies in Solomon Islands. PLoS Negl Trop Dis 15(2):e0009142. https:// doi.org/10.1371/journal.pntd.0009142

23. Ugbomoiko US, Oyedeji SA, Babamale OA, Heukelbach J (2018) Scabies in resource-poor communities in Nasarawa state, Nigeria: epidemiology, clinical features and factors associated with infestation. Trop Med Infect Dis 3(2):59. https://doi.org/10.3390/tropi calmed3020059

24. Korycinska J, Dzika E, Kloch M (2020) Epidemiology of scabies in relation to socio-economic and selected climatic factors in north-east Poland. Ann Agric Environ Med 27(3):374-378. https://doi.org/10.26444/aaem/109319

25. Inanir I, Sahin MT, Gündüz K, Dinç G, Türel A, Oztürkcan S (2002) Prevalence of skin conditions in primary school children in Turkey: differences based on socioeconomic factors. Pediatr Dermatol 19(4):307-311. https://doi.org/10.1046/j.1525-1470. 2002.00087.x

26. Middleton J, Cassell JA, Jones CI, Lanza S, Head MG, Walker SL (2018) Scabies control: the forgotten role of personal hygieneauthors' reply. Lancet Infect Dis 18(10):1068-1069. https://doi. org/10.1016/S1473-3099(18)30558-9

Publisher's Note Springer Nature remains neutral with regard to jurisdictional claims in published maps and institutional affiliations. 